\title{
Remembrance and Learning Skills and Their Relationship to Academic Achievement among University Students
}

\author{
Mohammad Omar AL-Momani ${ }^{\mathrm{a}, *}$ \& Elham Mahmoud Rababa ${ }^{\mathrm{b}}$ \\ ${ }^{a}$ Educational Sciences Department, Ajloun University College, Al-Balqa Applied University, Jordan \\ ${ }^{b}$ Ph.D in Psychological and Educational Counseling, SOS Children's Villages, Jordan
}

\begin{abstract}
The study aimed to identify the memory and learning skills and their relationship to academic achievement among university students in Jordan. The descriptive approach was used in addition to the questionnaire as a tool for the study. The study sample consisted of (1000) university students from different universities, colleges ,specializations and levels of study in different Jordanian universities , and the study was applied The study was conducted in the second semester of the academic year (20202021), and the study reached a set of results, which is that university students in general possess a high level of learning skills, recall and academic achievement, in addition to the existence of a direct relationship between learning, recall and academic achievement for the members of the research sample. The study concluded that there are significant differences in the skills of learning, memorization and academic achievement between the academic disciplines of the female students (scientific and human) and in favor of the scientific specialization.
\end{abstract}

Keywords: Study skills, learning, academic achievement, university students.

\section{Introduction}

The learning process is one of the necessary stages in the student's life ,as it is not limited to the practical material only, but also the educational and educational aspect of all aspects of life, and all these elements work to evaluate the student's personality and determine the level of academic achievement.

Therefore, learning and memorization skills are among the most important stages of the student's learning process and depend on what the student acquires of information based on the material given to her during the lesson and the nature of the student's mental processes through which she can program what she has obtained from the material and keep it in her imagination to benefit from it in the exam. There is a difference between individuals in the process of retaining the scientific material, as there are individual differences between them in mental operations, and thus this will affect the academic achievement process .

Through what was previously mentioned, the importance of the research is evident in trying to identify the level of memory and recall skills and the level of academic achievement of university students in various Jordanian colleges and universities, as well as identifying the differences in the level of the two variables for female students according to the variable nature of the academic specialization (human, scientific)

\subsection{Research Problem}

The learning and memorization processes and their major role in determining the nature of the student's scientific level, but also depends on the nature of the student's keenness and many important aspects, so this difference will also generate a difference in the academic level, so we will try through this research to determine the extent to which the students in the research sample possess the skills of memorization and learning As well as the level of academic achievement they have, as well as identifying the type of relationship between the two variables under study, and 
whether the type of specialization (scientific and humanitarian) has a role in the presence of a difference between the sample members.

\subsection{Research Aims}

a. Identifying the level of learning and memorization skills and the level of academic achievement among university students.

b. Identifying the relationship between learning skills, recall and academic achievement among the research sample .

c. Identifying the differences in the level of learning, recall and academic achievement between the nature of the academic specialization (human, scientific).

\subsection{Research Hypotheses}

a. There is a statistically significant relationship between the learning and memorization skills and the level of academic achievement of the research sample.

b. There are statistically significant differences between learning skills ,memorization and academic achievement in the type of specialization (scientific, human).

\subsection{Search Parameter:}

- The human field: female university students in various Jordanian universities and at different levels of study.

- Time domain: The study was applied in the second semester of the academic year (2020-2021)

- Spatial domain: The study was applied in a number of Jordanian universities and in various faculties, whether scientific or humanitarian.

\section{Theoretical Framework}

\subsection{The concept of learning and recall skills:}

Several definitions of the concept of learning and recall skills have emerged ,including what expresses a behavioral pattern that the student acquires through her repeated practice of collecting knowledge and information and mastering experiences and skill (El-Sayed, 2019).

They are also learned behavioral patterns, which are repeated in similar situations, and help to save time and effort, and to master the educational experiences of female students, and they differ according to different disciplines and individuals (Badir, 2020.)

It also represents special behavioral patterns that the student acquires through her repeated experiences in achievement and acquiring experiences (Al Shaarawy, 2017.)

Or they are the special methods that the student will follow in understanding the subjects that she has studied, or that she will study, through which the student learns facts, examines opinions and procedures, analyzes, criticizes, interprets phenomena, solves problems ,invents new ideas, masters and creates performances It requires speed and accuracy and acquires new behaviors that benefit it in its field of specialization (Abd. al-Nabi, 2016). 
So, through what was mentioned previously, we can define learning and recall skills as the most important practices and behavioral methods that female students usually practice when they remember and learn the subjects.

\subsection{The concept of academic achievement}

Achievement is of great importance in the life of the individual and society, and arises from needs such as the pursuit of excellence, the achievement of lofty goals, and success in difficult work.

Academic achievement as: competence in performance, which is an acquired ability rather than an inherited ability, and is usually measured by a specific assignment or a standardized test (Warren, 1934). Finger and Schlesser (1956) knew him that: the tendency to make the effort to achieve school success and Good (1973) know that is: acquired knowledge or skills in school subjects, usually determined by teacher testing or assessments, or both.

It also represents the amount of desire and tendency to make the effort to perform the duties and academic tasks well (Majid, 2019), so through what was mentioned previously, we find that the concept of academic achievement is represented in the amount of desire and tendency of the student to make the effort, as it can be inferred from that through the degree that the student obtains through her answer to the scale used to measure the level of academic achievement motivation.

\subsection{Forming Achievement Behavior}

The achievement can be formed from the influence of the following factors (Al-Azargawi, 2020):

a. Family

The family plays an important role in shaping academic achievement needs academic achievement, where parents who get high scores on achievement tests emphasize the importance of success and independence, and these parents reward their children for achievements, such as becoming pioneers, making friends, trying to do difficult tasks themselves, and persevering in performance. Children with strong needs for achievement to participate emotionally in the work performed by their children that is related to achievement.

The need for achievement also exists strongly in families that give their children opportunities to be independent and self-reliant at an early age.

\section{b. Teachers}

Teachers play an important role in developing behavior related to achievement ,as during the last years of primary school they use feedback patterns. Feedback which helps the ability and efficiency in the situations of achievement.

It is worth noting that the primary school years have a major impact on the development or impediment of the need for achievement in the secondary stage, and then the impact of both stages on achievement during the university stage.

\section{c. Society}

Society plays an active role in the development of achievement in individuals, as William James pointed out William James that there are valuable achievements in American society; including for example: that the individual's rank should be the first, and progressing forward, etc. Often, achievement in America is accompanied by material rewards: material profits, influence, and a distinguished social position. As a result, American children develop strong needs for achievement.

McClelland has done McClelland and his colleagues conducted studies on the need for achievement. In his study of human civilizations, he found that advanced peoples are distinguished by the strong level of need for achievement in them, as they seek success, mastery and control over their physical environment. 


\section{Research methodology}

The researchers used the descriptive approach to suit the nature of the research problem and its objectives. The research community included female university students in different Jordanian universities, and the sample was randomly selected with a rate of 1000 female students, and the table 1 illustrates this.

Table 1. The distribution of the sample according to the type of study specialization for the female students

\begin{tabular}{ccc}
\hline Specialization & The number & Percentage \\
\hline Scientific & 500 & $50 \%$ \\
Humanitarian & 500 & $50 \%$ \\
Total & 1000 & $100 \%$ \\
\hline
\end{tabular}

\subsection{Search Tools}

The scientific sources and the learning and recall skills scale of Mahmoud (2018), which consisted of 112 items, were relied on. As for the academic achievement scale, it was based on a scale of Hussain (2015) consisting of 40 paragraph. The two scales were presented to a group of experts and specialists in the disciplines of measurement, evaluation, curricula, teaching, and psychological and educational counseling.

\subsection{Survey Experience}

The experiment was conducted on 12/4/2021 on 30 female students from the same study community, but from outside the sample, during which the sample's understanding of the scale's expressions was identified and whether there is ambiguity mentioned in the answer to avoid every possible problem that may occur in the main application process of the scale.

\subsection{The Method of Correcting the Two Scales}

The memorization and learning scale consists of 112 items and the answer to them is according to (5-1) degrees for each item and according to the five alternatives, which are (always, often, sometimes, rarely, never) and with values according to the sequence $(1,2,3,4,5)$, for negative paragraphs and vice versa for positive. As for the academic achievement scale, it consists of 30 items, and the answer is (5-1) and according to the alternatives (strongly agree, agree, I don't know, disagree, strongly disagree) and evaluated according to the sequence $(5,4,3,2,1)$ for negative paragraphs and vice versa for positive.

\subsection{Calculation of the Total Score}

Since the memorization and learning scale consists of 112 items, the highest score for the answer will be 560, the lowest score is 112 , the arithmetic mean is 431.54 , and the standard deviation is 34.90 , and the academic achievement scale consists of 40 paragraph, the highest score is 200 and the lowest score is 40 , and the arithmetic mean of the scale is 194.72 and the standard deviation is 10.12 .

\subsection{The Validity and Reliability of the Study Tool}

\section{a. Honesty}

Honesty is one of the scientific conditions and characteristics of a good test, as honesty means "that the test measures what is designed to be measured and does not measure anything else" (Bahi, 2020). 


\section{b. Stability}

Cronbach's alpha equation was used to extract the stability coefficient, and it reached for the memorization and learning scale (0.84) and for the academic achievement scale (0.82), which is a high indicator of the stability of the two scales.

\subsection{The Main Experiment}

This was done during the break between lectures, which was from 2/5/2021 to 2021/5/27 when the two scales forms were distributed to the research sample, which amounted to 1000 female students, and after marking them by the sample, the forms were collected to obtain the research results .

\section{Results and Discussions}

\subsection{Identifying the Level of Memorization and Learning and the Level of Academic Achievement of University} Students

After collecting the data, it was necessary for us to identify what the sample possesses in terms of recall and learning skills, so this required extracting the value of $(t)$ between the arithmetic mean and the hypothetical mean of the research sample and the table (2) shows that.

Table 2. The relationship between the arithmetic mean and the hypothetical mean of the memory and learning skills

\begin{tabular}{|c|c|c|c|c|c|c|c|c|}
\hline \multirow{2}{*}{ Variable } & \multirow{2}{*}{$\begin{array}{l}\text { Sample } \\
\text { number }\end{array}$} & \multirow{2}{*}{$\begin{array}{l}\text { Arithmetic } \\
\text { mean }\end{array}$} & \multirow{2}{*}{$\begin{array}{l}\text { Standard } \\
\text { deviation }\end{array}$} & \multirow{2}{*}{$\begin{array}{l}\text { Hypothetical } \\
\text { mean }\end{array}$} & \multirow{2}{*}{$\begin{array}{l}\text { Degree of } \\
\text { freedom }\end{array}$} & \multicolumn{2}{|c|}{ Values T } & \multirow{2}{*}{ Indication } \\
\hline & & & & & & Calculated & Tabular & \\
\hline $\begin{array}{l}\text { University } \\
\text { students }\end{array}$ & 1000 & 324.62 & 8.13 & 321 & 148 & 3.89 & 2.02 & Moral \\
\hline
\end{tabular}

It is clear to us from table 2 that the arithmetic mean of the sample has reached its arithmetic mean (324.62), which is higher than the hypothetical mean, which indicates that the female students possess a high level of memorization and learning skills.

As for the academic achievement variable, the arithmetic mean, standard deviation, and hypothetical mean were extracted, as in Table 3.

Table 3. The relationship between the arithmetic mean and the hypothetical mean of the academic achievement variable

\begin{tabular}{|c|c|c|c|c|c|c|c|c|}
\hline \multirow{2}{*}{ Variable } & \multirow{2}{*}{$\begin{array}{l}\text { Sample } \\
\text { number }\end{array}$} & \multirow{2}{*}{$\begin{array}{l}\text { Arithmetic } \\
\text { mean }\end{array}$} & \multirow{2}{*}{$\begin{array}{l}\text { Standard } \\
\text { deviation }\end{array}$} & \multirow{2}{*}{$\begin{array}{l}\text { Hypothetical } \\
\text { mean }\end{array}$} & \multirow{2}{*}{$\begin{array}{l}\text { Degree of } \\
\text { freedom }\end{array}$} & \multicolumn{2}{|c|}{ Values T } & \multirow{2}{*}{ Indication } \\
\hline & & & & & & Calculated & Tabular & \\
\hline $\begin{array}{l}\text { University } \\
\text { students }\end{array}$ & 1000 & 214.21 & 7.89 & 138 & 142 & 4.17 & 2.88 & Moral \\
\hline
\end{tabular}

As it becomes clear to us from table 3 that the value of the arithmetic mean of the sample has reached its arithmetic mean (214.21), which is higher than the hypothetical mean, which indicates that the sample possesses a high level of academic achievement . 


\subsection{Identifying the Relationship between Memory and Learning Skills and Academic Achievement for the Study Sample}

In order to identify the type of relationship between the variables of study and learning and academic achievement, we had to find a Pearson test between the two variables and Table 4 shows that.

Table 4. The relationship between the research variables

\begin{tabular}{clccccc}
\hline NS & Variables & $\begin{array}{c}\text { Correlation } \\
\text { coefficient }\end{array}$ & $\begin{array}{c}\text { degree of } \\
\text { freedom }\end{array}$ & $\begin{array}{c}\text { Calculated } t \\
\text { value }\end{array}$ & t-table Value & Link type \\
\hline 1 & $\begin{array}{l}\text { Remember } \\
\text { and learn }\end{array}$ & 0.231 & 281 & 3.02 & 2.21 & moral \\
2 & $\begin{array}{l}\text { Academic } \\
\text { achievement }\end{array}$ & & & & & \\
\hline
\end{tabular}

Table 4 shows that the correlation between the two variables of the research is a significant correlation, that is, it is a positive correlation, and this is due to many factors, despite the different specializations of the students, but the process of students recalling information and the process of retaining information is based on the information they possess during the study period. The college and study materials have a major role in the process of students recalling information and thus achieving the new academic achievement. The parents also have a major role in guiding the student towards good achievement and providing the appropriate conditions to achieve this, as the educated and conservative family greatly affects the student's academic achievement and in many aspects related to her life University and increase motivation towards excellence, commitment to family directives.

\subsection{Knowing the Differences in the Level of Learning and Memorization Skills in the Light of the Academic} Specialization Variable (Scientific - Human)

In order to extract this, it was necessary for us to find the value of $t$ (calculated between the academic disciplines of the female students) (scientific and humanities), as in Table 5.

Table 5. The significant differences in the level of memory and learning skills in the light of the female students' academic specialization variable

\begin{tabular}{cccccc}
\hline Variable & $\begin{array}{c}\text { Arithmetics } \\
\text { mean }\end{array}$ & $\begin{array}{c}\text { Standard } \\
\text { deviation }\end{array}$ & Calculate t-value & t-table value & Indication \\
\hline Scientific & 298.21 & 34.13 & 9.45 & 2.18 & Moral \\
Humanitarian & 277.45 & 22.30 & & & \\
\hline
\end{tabular}

Table 5 shows the significant differences in the level of memory and learning skills in the light of the students' academic specialization (scientific, human) and in favor of the scientific specialization, due to the nature of the study and the different practices dictated to the student, which are represented in the practical field practiced by the scientific side, which strengthens the sobriety of the student's information .

\subsection{Knowing the Differences in the Level of Academic Achievement in the Light of the Variable of Academic Specialization for the Female Students (Scientific - Human)}

In order to know this, it is necessary to find the value of $\mathrm{t}$ (calculated between the scientific and humanistic disciplines), as shown in Table 6. 
Table 6. The significant differences in the level of academic achievement in the light of the variable of academic specialization for the female students (scientific, human)

\begin{tabular}{cccccc}
\hline Variable & $\begin{array}{c}\text { Arithmetics } \\
\text { mean }\end{array}$ & $\begin{array}{c}\text { Standard } \\
\text { deviation }\end{array}$ & Calculate t-value & t-table value & Indication \\
\hline Scientific & 115.89 & 17.34 & 9.56 & 1.96 & Moral \\
Humanitarian & 113.23 & 23.75 & & & \\
\hline
\end{tabular}

It becomes clear to us by observing Table 6, the significant differences in the level of academic achievement in the disciplines (scientific ,human), where we find that the relationship is significant between the two variables in favor of the scientific specialization, because the nature of female students in the scientific specialization has a higher level of academic achievement and for many reasons, including the level Scientific .

\section{Conclusions and Recommendations}

\subsection{Conclusions}

1) University students in general possess a high level of learning skills, memorization and academic achievement.

2) There is a direct relationship between learning, recall and academic achievement of the research sample members .

3) The existence of moral differences in the skills of learning, recall and academic achievement between the academic disciplines of the female students (scientific and human) and in favor of the scientific specialization.

\subsection{Recommendations}

1) Orienting students to the importance of good academic achievement, which has a major role in strengthening the student's personality.

2) Involve female students in artistic and sports activities in order to diversify their activity and increase the desire for achievement by creating a new and enjoyable atmosphere for the student.

3) Benefiting from the results of the research in the opening of new programs that meet the needs of students and the community, including the development of new curricula that are of medium difficulty and do not provoke them boredom, in line with the current developments and developments in society, and help to achieve adaptation with the changes and needs of society through the formation of the appropriate personal experience to achieve this In order to ensure the solution of the students 'scientific, social, psychological and economic problems.

4) Conducting a similar study of the current research variables and on the male sample in order to compare with females in the results that have been reached and to identify the reasons for the differences, if any, between the sexes.

\section{References}

Abd al-Nabi, M. H. Learning and Recalling Skills for Mentally Outstanding and Ordinary High School Students, Second Annual Conference of the Department of Educational Psychology, College of Education, Mansoura University. 
Al-Shaarawy, A. M. G. (2017). Recollection habits and preferred learning style and their relationship to test anxiety among secondary school students, Journal of the College of Education, Mansoura University, 29.

Al-Azargawi, F. M. (2020). Educational Psychology. Mosul, Iraq: Mosul University Press.

Badir, M. N. (2020). Study habits and their relationship to academic achievement among male and female university students. Journal of the College of Education, Al-Mansour University, 14(2).

Bahi, M. (2020). Scientific transactions between theory and practice. Cairo: Al-Kitab Center for Publishing.

El-Sayed, A. Q. Z. (2019). Reflection habits in relation to specialization and the level of academic achievement in high school for a sample of students from the College of Education, King Saud University, The Sixth Annual Conference of Psychology in Egypt, Cairo, Egyptian Association for Psychological Studies.

Finger, J. A., \& Schlesser, G. E. (1965). Non-intellective predictors of academic success in school and college. The School Review, 73(1), 14-29.

Good, C. V., \& Merkel, W. R. (1973). Dictionary of education. $3^{\text {rd }}$ edition. McGraw-Hill.

Mahmoud, N. A. (2018). Learning and recall skills and their relationship to learning motivation among middle school students in the light of some variables. Unpublished master's thesis, Mosul.

Majid, A. H. (2019). The level of academic achievement motivation for students of faculties of education in Iraqi universities. Unpublished Master's Thesis, Salah El-Din University, College of Education.

Warren, H. C. (1934). Dictionary of psychology Cambridge. Massachusetts: Houghton Mifflin. 